\title{
Factors Shaping the Image of Badung Traditional Market in Denpasar City, Bali Province
}

\author{
I Nyoman Gede Ustriyana
}

Study Program of Agribusiness, Faculty of Agriculture, Udayana University, Indonesia

\begin{abstract}
In the midst of rapid development of modern markets, traditional markets everywhere, including Badung traditional market in Denpasar City, still play an important role in bringing consumers and producers together and have the advantage as a place of price and quantity bargains. The purpose of this study is to identify the factors shaping the image of Badung traditional market in Denpasar City, Bali Province. The samples of this study were 100 consumer respondents using convenience sampling. The analytical method used in this research was factor analysis. The study shows that there are six factors forming the image of Badung traditional market, namely price, service, quality, physical environment, location and variety of goods. Service factor has the most dominant loading value in shaping the image of traditional market, followed by the location factor. Both of these factors are still the dominant factors that shape the image of the traditional market. The roles of other factors need to be improved, such as the price factor that is considered to be competing with modern markets, the quality factor that needs to be improved, as well as the diversity of goods that have been deemed unable to compete with modern markets.
\end{abstract}

Keywords-Market image, traditional market, factor analysis.

\section{INTRODUCTION}

Lately the presence of traditional markets has been shifted by the emergence of and massive competition with modern retail business. The existence of a retail business, or commonly referred to as retailers, has been increasingly noticeable in community daily life. A wide variety of retail shopping centers has sprung up in various shapes and dimensions.

There are several factors that can influence people to shop in traditional markets; some of them even have always been very loyal. Loyalty is a pleasing feedback towards a brand/product/place shown by consistent purchases of the product all the time (Sutisna, 2003). Thus, in this case, consumers have loyalty towards the existence of traditional markets.
According to Iswari and Suryandari (2003), there are several factors that may influence consumer decisions to make purchases or, even more, to be loyal. The factors can be measured with variables, such as price, service, quality, physical environment, location and variety of goods. One of the virtues of traditional markets is the negotiable price for buyers; hence, the price shall be the consent of the seller and the buyer. On the other hand, traditional markets also have their deficiencies, among others; quickly withered produce, dirty and hot environment, as well as crowded and muddy location.

Badung traditional market is one of the traditional markets that has many loyal consumers in Bali Province. Although this market has many competitors from other traditional markets, Badung traditional market remains to be deemed as the largest and most spacious market with plenty of visitors. Despite having many loyal customers, the emergence of minimarkets and supermarkets in Denpasar City, such as Tiara Group, Hardys, Indomaret, Alfamart, Hypermart, Carrefour, may result in the decreasing number of customers visiting Badung traditional market. There are many factors that influence consumer loyalty at Badung traditional market, such as price, service, quality, physical environment, location and variety of goods.

The purpose of this study is to identify the factors that form the image of Badung traditional market in Denpasar City, Bali Province, among six main dimensions forming the market image.

\section{LITERATURE REVIEW}

A traditional market is a market that can accommodate a lot of sellers with simple management and is usually for the middle and lower class population, which operates from dawn until afternoon, or even evening. Currently, modern markets offer many advantages, such as a larger and more comfortable space and a fixed price.

Image is an overall perception of a brand or product formed from past information and fragments of the product or brand (Sutisna, 2003). Image is also associated with the attitude in the form of beliefs and preferences towards a certain 
product (Mayasari, 2009). Consumers having a positive image of a product are more likely to purchase and develop a product; this is where an advertisement is very useful in creating a positive image of a product. There are six factors that can create image of a product, such as price, service, quality, physical environment, location and variety of goods.

Price. Price is the amount of money needed to obtain some combinations of a product and its accompanying services (Angipora, 2002). Furthermore, Tanjung (2004) states that price is the amount of money that has been agreed by potential buyers and sellers in exchange for goods or services within the normal business transactions.

The price variable is one of the variables that must be controlled in a harmonious manner with the goal to be achieved by the company. Decisions related to price will affect other aspects of the company activities, such as sales and profits to be achieved (Angipora, 2002).

The price factor also draws attention in price fixing, especially. Kotler (2005) states that there are five factors to consider before fixing a price of a product, among others: (1) pricing objectives, (2) determination of demand, (3) cost estimation, (4) analysis of competitor cost, price and offer, and (5) pricing method.

Service. Service is an act or deed that can be offered by one party to another, which is essentially intangible and may result in ownership (Tjiptono, 2005). Service is an intangible performance and disappears quickly; it can be felt rather than owned, and customers can participate more actively in the process of consuming these services. Good market service facilities, ease of pickup, delivery of credit and comprehensive goods service are some of the considerations that affect the level of customer satisfaction towards supermarkets.

Service that is received or perceived as expected by the consumers is considered as a good or satisfactory service. Conversely, if the service received is lower than expected, then the service is perceived as a poor service.

Quality. Quality is a dynamic condition in relation to products, services, people, processes, and environments that meet or exceed expectations (Tjiptono, 2005). In addition, Purnama (2006) defines quality as the overall traits and characteristics of a product or services on the ability to meet the needs that have been determined or is patent.

In a competitive situation, the quality of a product becomes a central issue for every company. The company ability to provide products with excellent quality will become a weapon to win the competition, because by providing such products, customer satisfaction is achieved.

Physical environment. Physical environment is any physical form surrounding the consumers, which includes a variety of products, stores, as well as location inside the store (Sumarman, 2003). The physical environment includes a comfortable space, room layout, physical form and a parking lot. For example, a house is a microphysical environment for consumers that will influence the attitudes and behavior of consumers directly.

When observed closely, many consumers are purchasing products that are not previously planned. The desire to buy a product may appear suddenly due to various situational motives, such as motivated by the physical environment of the market. Although the purchasing behavior because of a situational pressure does not take place continuously in each individual, every customer must have purchased a product as a result of situational pressures (Sutisna, 2003).

Location. Location variable is related to the location where the company should be headquartered and run its operations (Lupioadi, 2001). The location is the place or spot used as offices by a company in selling and offering products.

A so-called strategic location is that in the center of the city with a certain population, with an easy access in regard to public transportation, smooth traffic, as well as pedestrianfriendly. The importance of location for service companies depends on the type and degree of interaction involved. In determining the location, a company needs to look at the type of customer interaction and services provided (Lupioadi, 2001).

Companies are always trying to find a strategic business location, which is easily engaged by and affordable for the consumers (Sumarwan, 2003). Location greatly affects a person desire to make a purchase. If the consumers are unable to easily access the location, they will not be interested to visit.

Engel, et al. (1995) states that the location has several indicators, among others; ease of transportation, short travel time requirement, short distance from the house to the market, strategic location, and the location that is close to the center of the crowd. Thus, there are many factors to be considered for the market location to get the consumer attention.

Diversity of goods. The diversity of goods is the completeness of the goods sold and the availability of these items. Consumers will choose a market that has complete goods that can meet all of their needs and desires.

According to Engel, et al. (1995), indicators of the diversity of goods are the completeness of the product being sold, 
product variety, availability of products sold, as well as variety of brands that are available. The traditional market that has a variety of goods will surely be the proper location for consumers to obtain all their needs.

\section{ANALYTICAL METHOD}

\section{Population Overview}

Population is a combination of all elements that have a series of similar characteristics including variables needed for a marketing research (Malhotra, 2004). The population in this study was the people who used the Badung market as a location for activities of sales and purchasing of daily consumer goods.

\section{Sampling Technique}

The sampling technique used in this study was a nonprobability sampling technique, in which all of the population did not have the same opportunities to become respondents and the sampling was based on consideration of the researcher. The total number of the samples was set out by using the Slovin formula (see Sugiyono, 2008), which was as many as 96.04 persons (rounded to 100 consumers). The determination of the respondents was conducted by using purposive sampling method (judgment sampling), which is a technique of non probability sampling in which the researcher selected a number of people based on the specific characteristics to the sample and considered to have a close connection to the population traits or characteristics that had been known previously; that the respondents were previously aware of the existence of Pasar Badung.

\section{Identification and Definition of Variables}

The variable in this study was the image of the traditional market. The explanation of each variable is shown in Table 1.

Table.1: Variable, Definition and Study Indicator

\begin{tabular}{|c|c|c|c|}
\hline No & Variable & Definition & Indicator \\
\hline 1. & Price & $\begin{array}{l}\text { The amount of money that has been agreed } \\
\text { by potential buyers and sellers in exchange } \\
\text { for goods or services within the normal } \\
\text { business transactions. (Tanjung, 2004) }\end{array}$ & $\begin{array}{ll}\text { a. } & \text { Affordable price } \\
\text { b. } & \text { Competitive price } \\
\text { c. } & \text { Cheaper price } \\
\text { d. } & \text { Price based on quality } \\
\text { e. } & \text { Price variety }\end{array}$ \\
\hline 2. & Services & $\begin{array}{l}\text { An act or deed that can be offered by one } \\
\text { party to another, which is essentially } \\
\text { intangible and may result in ownership } \\
\text { (Tjiptono, 2005) }\end{array}$ & $\begin{array}{l}\text { a. Fast services from sellers } \\
\text { b. Friendly attitude of sellers } \\
\text { c. Focusing on customer satisfaction } \\
\text { d. The availability to complain and give } \\
\text { suggestions }\end{array}$ \\
\hline 3 & Quality & $\begin{array}{l}\text { A dynamic condition in relation to products, } \\
\text { services, people, processes, and environment } \\
\text { that meet or exceed expectations (Tjiptono, } \\
2005 \text { ) }\end{array}$ & $\begin{array}{l}\text { a. Product quality competitive to supermarket } \\
\text { standards } \\
\text { b. Quality of products sold in accordance with the } \\
\text { offered price } \\
\text { c. Varied quality of products sold } \\
\text { d. Product quality that meet the criteria for sale }\end{array}$ \\
\hline 4. & $\begin{array}{l}\text { Physical } \\
\text { environmen } \\
\mathrm{t}\end{array}$ & $\begin{array}{l}\text { Any physical form surrounding the } \\
\text { consumers, which includes a variety of } \\
\text { products, stores, as well as location inside } \\
\text { the store (Sumarman, 2003) }\end{array}$ & $\begin{array}{l}\text { a. Parking lot } \\
\text { b. The room layout } \\
\text { c. The physical location } \\
\text { d. Convenient place }\end{array}$ \\
\hline 5. & Location & $\begin{array}{l}\text { Related to the location of where the } \\
\text { company should be headquartered and run its } \\
\text { operations (Lupioadi, 2001). }\end{array}$ & $\begin{array}{l}\text { a. Easy transportation } \\
\text { b. Short travel time required } \\
\text { c. The close distance from home to the market } \\
\text { d. Strategic location } \\
\text { e. The location near the center of the crowd }\end{array}$ \\
\hline 6. & $\begin{array}{l}\text { Diversity of } \\
\text { goods }\end{array}$ & $\begin{array}{l}\text { The completeness of the goods sold and the } \\
\text { availability of these items. }\end{array}$ & $\begin{array}{l}\text { a. } \\
\text { b. Product variety } \\
\text { c. Availability of products sold } \\
\text { d. Variety of brands that are available }\end{array}$ \\
\hline
\end{tabular}




\begin{tabular}{|l|l|l|l|l|} 
7. & Consumer's & $\begin{array}{l}\text { Loyalty is a pleasing feedback towards a } \\
\text { brand/product/place shown by consistent } \\
\text { purchases of the product all the time } \\
\text { loyalty }\end{array}$ & $\begin{array}{l}\text { b. Satisfaction with the product purchased } \\
\text { c. Satisfaction with the purchasing location } \\
\text { d. The desire to recommend to others }\end{array}$ \\
\hline
\end{tabular}

\section{Data Analysis Method}

A method of data analysis used in this study was an analysis of confirmatory factor. According to Ghosali (2009), the main purpose of factor analysis is to conceptually define the structure of a data matrix and analyze structures that are interconnected. By using a factor analysis, the identification phase can be conducted that is how to summarize the information contained in the original variables into a set of new dimensions/factors. In addition, by using the factor analysis, the measurement of how variables can be explained by the new dimension composing it.

\section{RESULTS AND DISCUSSION}

Kaiser-Meyer-Olkin (KMO)Test and Bartlett's Test are two conformance data tests performed prior to interpreting the results of factor analysis. Measure of sampling adequacy (MSA) is a statistic that indicates the proportion of variance in the variables that can be used as the foundation in the use of factor analysis. If the value of MSA is > 0.50, then the variable can be predicted and analyzed further. Bartlett's Test is used to test whether the variables used are not correlated and suitable to be used for factor analysis. If Bartlett's Test generates significant value of $<0.05$ ( \& = $5 \%$ ), then the variables are not correlated and suitable for factor analysis. Below is the result of KMO and Bartlett's Test results generated from factor analysis.

In Table 2, it can be seen that the value of KMO is 0.804 (> $0.5)$, so it is concluded that the variables used in this study can be predicted and can be analyzed further. Table 3 also shows that the value of Bartlett's Test resulted in the significant value of $0.000(<0.05, \alpha=5 \%)$, so it is concluded that variables used in the study are correlated and suitable for factor analysis.

Table.2: The Value of KMO and Bartlett's Test on the Factors Shaping the Image of Badung Traditional Market in Denpasar City, Bali Province

\begin{tabular}{|c|c|c|}
\hline & \\
\hline \multirow[t]{3}{*}{ Bartlett's Test of Sphericity } & & \\
\hline & Df & 325 \\
\hline & Sig. & .000 \\
\hline
\end{tabular}

Communalities show how much origin diversity variable can be explained by the formed factor. Table 3 demonstrates the commonality value resulting from factor analysis. It shows that the communality of 26 variables used is above the average value of 0.50 ; this means that the formed factors can explain at least $50 \%$ of the diversity of the origin diversity variables.

Table.3: Communalities Value on the Indicators Shaping the Image Factors of Badung Traditional Market in Denpasar City, Bali Province

\begin{tabular}{|c|c|c|c|}
\hline Indicator & Communalities Value & Indicator & Communalities Value \\
\hline 1 & .722 & 14 & .643 \\
\hline 2 & .695 & 15 & .720 \\
\hline 3 & .708 & 16 & .729 \\
\hline 4 & .637 & 17 & .738 \\
\hline 5 & .652 & 18 & .586 \\
\hline 6 & .523 & 19 & .891 \\
\hline 7 & .683 & 20 & .891 \\
\hline 8 & .719 & 21 & .621 \\
\hline 9 & .764 & 22 & .764 \\
\hline 10 & .425 & 23 & \\
\hline
\end{tabular}




\begin{tabular}{|c|c|c|c|}
\hline 11 & .561 & 24 & .699 \\
\hline 12 & .734 & 25 & .694 \\
\hline 13 & .604 & 26 & .718 \\
\hline
\end{tabular}

Eigen value is a value that indicates the amount of variance associated with each factor. Factors that have 1 (one) eugen value is incorporated into the model, while the factor with value less than 1 , shall not be incorporated into the model.
Table 4 shows that there are 6 factors that have eigenvalues of greater than 1 . The cumulative total of variance of original variables that can be explained by the six factors mentioned above is $67.885 \%$.

Table.4: Total Variance Explained by the Factors Shaping the Image of Badung Traditional Market in Denpasar City, Bali Province

\begin{tabular}{|c|c|c|c|}
\hline \multirow{2}{*}{ Component } & \multicolumn{3}{|c|}{ Initial Eigenvalues } \\
\cline { 2 - 4 } & Total & \% of Variance & Cumulative \% \\
\hline 1 & 8.406 & 32.332 & 32.332 \\
\hline 2 & 2.755 & 10.595 & 42.926 \\
\hline 3 & 2.121 & 8.159 & 51.085 \\
\hline 4 & 1.716 & 6.600 & 57.686 \\
\hline 5 & 1.431 & 5.503 & 63.189 \\
\hline 6 & 1.221 & 4.697 & 67.885 \\
\hline
\end{tabular}

To know the contents of each of these factors, it can be seen by looking at the value of the factor loading in Component Matrix Table. Factor loading shows greater correlation between a variable with the factors that are formed. The greater the value of a loading variable factor is, the more closely the relationship of these variables on the formed factor. In the factor loading, the varimax rotation is needed. Rotation is useful to minimize redundancy among the factors, because each of the factors explaining the origin of the diversity of each factor. From the results of varimax rotation, each factor would explain the greater diversity of one variable. Factor loading rotation resulted as follows.

Having determined that there are six factors that are formed, then the next step is to determine the feasibility of the indicators to be included in the factors. To determine which variable that will enter a factor can be seen from largest loading factor value. Rotated component matrix shows a clearer and more evident variable distribution. The explanations are as follows.

a) The first factor is the price in which the variables concern all matters relating to the price of products; acknowledged by the consumers as one of the things that is considered when a person/consumer wants to shop in traditional markets.

b) The second factor is the services; the variables are related to the services provided by the sellers and market managers that are perceived to give satisfaction to the consumers. c) The third factor is the quality; it is quite clear that the traditional markets provide a wide selection of quality to consumers.

d) The fourth factor is the physical environment in which Badung traditional market is considered to have a good physical environment as seen from the physical form of the building, the layout of the goods, as well as other matters relating to the existence of the market.

e) The fifth factor is the location in which Badung traditional market is considered to have the right location that is in downtown and easy to reach from home by any means of transportation.

f) The sixth factor is the diversity of goods in which the consumers assume that Badung traditional market is a market with various types of goods needed by consumers, both for their daily use and for other purposes.

\section{CONCLUSIONS AND RECOMMENDATIONS}

\section{Conclusions}

1. There are six factors forming the image of Badung traditional market, namely price, service, quality, physical environment, location and variety of goods.

2. Service factor, followed by the location factor, has the most dominant loading value in shaping the image of the traditional market. Both of these factors are the dominant factors that form the image of the traditional market. 


\section{Recommendations}

The roles of other factors should be enhanced. The price factor of the traditional market is considered competitive with modern markets. The quality factor needs to be improved. The diversity of goods that have been deemed unable to compete with modern markets needs to be expanded.

\section{REFERENCES}

[1] Angipora, Marius. 2002. Dasar-Dasar Pemasaran. Second Edition. PT Raja Grafindo Persada. Jakarta.

[2] Djarwanto and Pangestu Subagyo. 2000. Prosedur Penelitian Suatu Pendekatan Praktik. Revised Edition, PT Rineka Cipta Jakarta.

[3] Durianto, Darmadi, Sugiato and Toni Sitinjak. 2001. Strategi Menaklukkan Pasar: Melalui Riset Ekuitas and Perilaku Merek. PT GramediaPustaka Utama, Jakarta.

[4] Engel, James. F., R.D. Blackwell, and P.W. Miniard. 1995. Consumer Behavior. International Edition. USA. The Dryden Press Harcout Brace College Publishers.

[5] Iswari, Riana and Retno Tanding Suryandari. 2003. Analisis Pengaruh Citra Supermarket terhadap Loyalitas Konsumen. Jurnal Bisnis dan Manajemen, Vol. 3, No. 2. Universitas Sebelas Maret, Surakarta.

[6] Kotler, Philip. Alih Bahasa: Benyamin Molan. 2005. Manajemen Pemasaran. Eleventh Edition Volume 1. PT Intan Sejati Klaten. Jakarta.

[7] Kotler, Philip and Amstrong. 2001. Prinsip-Prinsip Pemasaran. Jakarta.

[8] Mayasari, Rani. 2009. Analisis Pengaruh Citra Pasar Tradisional terhadap Loyalitas Konsumen (Studi pada Pasar Projo di Ambarawa). Thesis of Faculty of Economy, Universitas Sebelas Maret. Surakarta.

[9] Purnama, Nursya'bani. 2006. Manajemen Kualitas: Persiapan Global. First Edition. First Edition. Ekonisia. Yogyakarta.

[10] Rangkuti, Freddy. 2002. The Power of Brand: Teknik Mengelola Brand Equity dan Strategi Pengembangan Merek. Jakarta: PT Gramedia Pustaka Utama.

[11] Sugiyono. 2005. Metode Penelitian Bisnis. Eighth Edition. CV Alfabeta. Bandung.

[12] Supardi. 2005. Metodologi Penelitian Ekonomi and Bisnis. First Edition. UII Press. Yogyakarta.

[13] Sutisna. 2003. Perilaku Konsumen and Komunikasi Pemasaran. PT. Remaja Rosdakarya. Bandung.

[14] Tanjung, Jenu Widjaya. 2004. Marketing Management: Pendekatan pada Nila-Nilai Pelanggan.
Second Edition. Second Edition. Bayumedia Publishing. Malang.

[15] Tjiptono, Fandidan Gregorius Chandra. 2005. Service Quality \& Satisfaction. First Editioin. Andi Jakarta. 